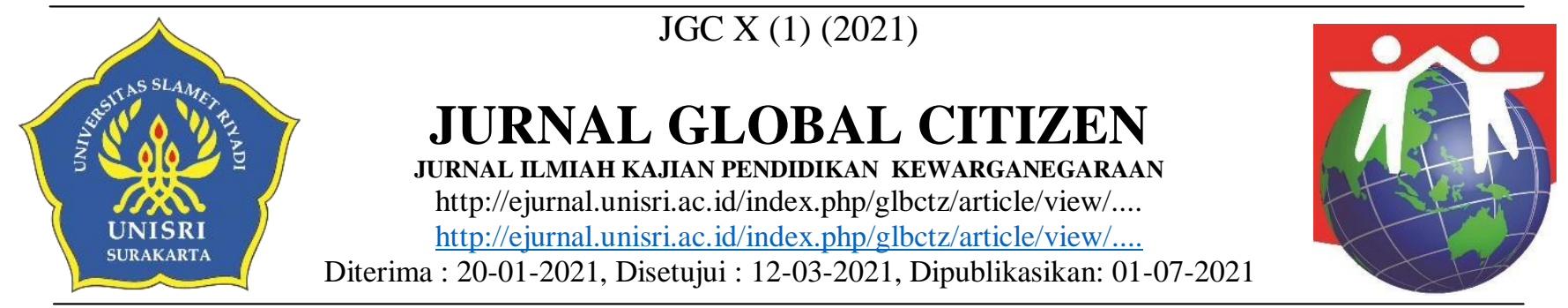

\title{
MEMBANGUN KEDEWASAAN DEMOKRASI DI INDONESIA
}

\author{
Wisnu Sri Admojo ${ }^{1}$, Anita Trisiana ${ }^{2}$, Sony Hermawan Susilo ${ }^{3}$ \\ Universitas Slamet Riyadi \\ Email : sriadmojo77@gmail.com, sonysusilo13@gmail.com
}

\begin{abstract}
ABSTRAK
Kematangan mahasiswa dan sarjana di Surabaya kurang tinggi. Beberapa siswa tidak dapat dan tidak dapat menerima perbedaan politik atau mengekspresikan kemauan politik mereka dengan baik. Mereka terkadang mengkomunikasikan niat politik mereka dengan mengambil tindakan anarkis. Pada saat yang sama, hal ini akan membahayakan persatuan negara kita, karena pelajar adalah bagian dari masa depan negara kita. Mengenai situasi ini, perlu dilakukan pembinaan terhadap mahasiswa yang memiliki kematangan politik yang memadai. Masalah pendidikan demokrasi dalam pendidikan kewarganegaraan merupakan solusi yang memungkinkan peserta didik untuk melakukan tindakan politik yang santun. Sebagai generasi penerus bangsa, mahasiswa juga diharapkan dapat memberikan kontribusi yang berarti bagi pembangunan di segala bidang kehidupan bangsa, baik di bidang politik, ekonomi, sosial budaya, politik dan demokrasi, hal ini benar adanya, karena semua warga negara berada di bidang hukum. Punya posisi yang sama pemerintah. Penerapan nilai-nilai demokrasi dapat membantu siswa memperoleh kedewasaan politik dan demokrasi. Oleh karena itu demokrasi merupakan informasi terpenting dalam negara dan kehidupan bernegara, serta merupakan upaya untuk menjaga keadilan.
\end{abstract}

\section{Kata Kunci : Membangun Kedewasaan Demokrasi di Indonesia}

\begin{abstract}
ABSTRACK
The maturity of students and academics in Bandung a is still not good enough. There are some students who cannot and cannot accept political differences or convey political aspirations them well.They sometimes convey their political intentions by doing anarchist action. Whereas at this time it will bring danger to the unity of our country because students are part of our country's future. In reference to this case, it is necessary make students into people who have adequate political maturity.Studentas the nation's future generations are also expected to make a big contribution development in all spheres of nationa llife, beitinthepolitical, economic, social fields culture, and politics and democracy are certainly not wrong,because all citizenshave the same positionn in law and government. The problem in democratic education in civic education is away of solution students do politely politically. The application of democratic values can help students to have political maturity and democracy. Therefore, themost important message of democracy in the life of the nation and state is an effort to maintain justice as fairly as possible.
\end{abstract}

\section{Key Words : Build Democratic Maturity in Indonesia}




\section{PENDAHULUAN}

Sejarah bisa membuktikannya diri mahasiswa sendiri. Negara Indonesia sadarilah dalam bentuk tujuan negaranya. Mahasiswa sebagai bagian dari hidup kampus adalah perubahan yang selalu saya inginkan buat perubahan bergerak ke arah yang lebih baik bijaksana. Mahasiswa kerap mengikuti kegiatan sosial ekonomi masyarakat, penegakan hukum dan kegiatan HAM, seperti Melakukan berbagai tindakan, seperti menggalang dana untuk membantu korban bencana alam, dan melakukan aksi. Demonstrasi yang menyampaikan keinginan atau pendapat terkait kebijakan pemerintah di kalangan masyarakat, kegiatan tersebut dinilai membebani masyarakat biasa. Sebelum 1998, kebebasan batin "Pemimpin" demokrasi itu terbuka, dan masyarakat kini tidak lagi takut menyampaikan harapan atau pidato politik. Banyaknya kasus katanya mungkin sudah dewasa hanya dari segi usia, dan saya belum melihat kematangan psikologis dalam siswa. Banyaknya demonstrasi anarkis merupakan indikator ketidak dewasaan mereka. Selain itu, kebutuhan utama siswa terkadang tidak tanggapi secara realistis yang muncul dalam di lingkungan mahasiswa,sering hanya ditanggapi secara kulitnya saja. Sesuatu gampang dipandang salah dan sesuatu yang lain gampang di pandang benar. Seolah tak ada pemikiran yang lebih jauh dalam bertindak. Lalu kalau demikian dimana letak kedewasaan seorang mahasiswa belum jelas Namun, bukan berarti berbanding lurus dengan prosesnya demokrasi. Politik yang berakhiran anarkisme menunjukkan gaya politik Siswa yang belum dewasa harus memainkan peran yang lebih aktif dalam berbagai hal, khususnya Ini menyangkut masalah nasional. Mahasiswa harus berperan lebih aktif dalam berbagai isu, terutama yang terkait dengan isu etnis. Selama ini siswa telah mendemonstrasikan fungsi kontrol. Masyarakat sangat berharap banyak untuk menangani Mereka menghadapi masalah siswa. Jadi jika siswa memiliki Banyak harapan dan tanggung jawab, hal ini tidak berlebihan. Banyak kebijakan pemerintah yang seringkali membebani perekonomian rakyat, dan terkadang mendorong mahasiswa untuk merespon kebijakan tersebut melalui demonstrasi publik. Tidak ada salahnya mengungkapkan pandangan ini di depan umum, Karena dijamin oleh undang-undang.

Sebagai generasi penerus bangsa, mahasiswa juga diharapkan dapat memberikan kontribusi yang besarbagi perkembangan berbagai bidang kehidupan bangsa (termasuk politik, ekonomi, sosial budaya dan agama). Dalam bidang politik, perilaku mahasiswa tidak diragukan lagi bagaimana mahasiswa menggulingkan kekuasaan tersebut berkuasa? bersamaan dengan 32 tahun rezim orde baru, negara ini juga memasuki era reformasi. Mahasiswa di bidang politik dan demokrasi tentunya Ya, karena semua warga negara memiliki status hukum dan pemerintahan, ini berarti mahasiswa otomatis dijamin kemampuan politiknya. Mengungkapkan pendapatnya sesuai dengan konstitusi terkadang dia akan mengambil tindakan anarkis, misalnya dengan menghancurkan internal dan berbagai fasilitas umum, atau mengakhiri konflik dengan perangkat keamanan.

Melihat fenomena tersebut, perlu adanya peningkatan kematangan politik warga negara Dalam hal ini, mahasiswa di kalangan akademisi diminta untuk menghindari terulangnya hal-hal yang berkaitan dengan anarkisme dan tidak terulang kembali. Sedangkan itu kita harus berusaha membangun kembali demokrasi di indonesia supaya demokrasi di indonesia bisa maju dan stabil,karena demokrasi di indonesia belum dapat memenuhi ataupun melengkapi persyaratan,seringkali kita lihat banyaknya masyarakat indonesia seringkali melakukan demo-dan tidak setuju dengan keputusan pemerintahan. Ditengah gencarnya pembangunan infrastruktur yang menjadi fokus rezim ini, banyak masyarakat yang menilai rezim Jokowi mengalami krisis demokrasi. Mulai dari pembubaran salah satu ormas yang dianggap mengancam falsafah negara Indonesia sampai penodaan demokrasi yang dilakukan penegak hukum akhir-akhir ini dengan ditangkapnya beberapa mahasiswa yang sedang melakukan demonstrasi.

Rezim ini mengalahkan keyakinan pemerintah itu sendiri akan kemampuannya 
dalam mengelola demokrasi. Konsolidasi demokrasi yang menjadi puncak tahapan transisi demokrasi akan sulit dicapai apabila pemahaman demokrasi antara pemeritah dengan masyarakat berbeda.

\section{METODE}

Dalam era reformasi, demokrasi sedang melanda kehidupan masyarakat, negara, dan negara, namun belum menemukan bentuk demokrasi atau masyarakat yang demokratis yang matang, dan seringkali menunjukkan sikap dan perilaku yang menyimpang dari norma-norma masyarakat yang demokratis. Berbagai upaya diperlukan untuk menjadi masyarakat yang demokratis, termasuk diantaranya yaitu melalui pendidikan kewarganegaraan. Tujuan pendidikan kewarganegaraan adalah membentuk warga negara yang demokratis, beradab, dan berbakat yang bertanggung jawab atas kelangsungan hidup negara dan negara.Keberhasilan demokrasi tercermin dari sejauh mana warga negara hidup bersama dan mencapai konsensus atas prinsip-prinsip demokrasi antara warga negara dan antara warga negara dengan negara. . Standar dibutuhkan sebagai acuan bagi tatanan sosial yang demokratis. Ini termasuk kesadaran akan keberagaman, musyawarah, kebebasan hati nurani, persamaan hak dan kewajiban, dan kejujuran dalam konsensus.

\section{HASIL DAN PEMBAHASAN}

Tidak ada kedewasaan atau kedewasaan dalam sikap seseorang, dan itu Ini tidak ada hubungannya dengan usia. Beberapa orang lebih tua, tetapi gaya berpikir dan sikap mereka belum dewasa, tetapi beberapa orang masih remaja, dan gaya berpikir serta sikap mereka menunjukkan bahwa mereka sudah dewasa. Dikatakan bahwa seseorang itu dewasa, termasuk dapat menerima ketidaknyamanan, bijaksana, tidak memiliki emosi, tidak suka menimbulkan masalah, Dan memiliki karakter yang baik.

Mahasiwa yang berkepribadian adalah

(1) Siswa yang berkarakter, kerinduan akan ilmu Pengetahuan dan kebenaran selalu berfikir keras untuk memecahkan masalah dan fenomena sosial dan alam secara intelektual, serta berpegang pada etika akademik dan keilmuan, sehingga terwujud kebebasan akademik dan beradab, bertanggung jawab, dan mewujudkan tanggung jawab moralnya yaitu memanfaatkan ilmu pengetahuan untuk kepentingan masyarakat.

(2) Siswa merupakan bagian dari sistem pendidikan nasional Republik Indonesia. Oleh karena itu kesadaran akan keberadaan formalnya harus diinternalisasikan ke dalam karakter peserta didik, sehingga peserta didik secara sadar menjadi bagian dari kehidupan bangsa pendidikan yang sadar. Kepentingan negara dan negara lebih tinggi dari pada kepentingan individu / kelompok, mengikuti prinsip konstitusi dan peraturan perundangundangan yang berlaku, serta bertanggung jawab atas masa depan negara dan negara.

(3) Mahasiswa adalah anak suatu negara dan bagian dari masyarakat. Baik sekarang maupun yang akan datang, mahasiswa adalah wakil rakyat.

Demikian Siswa adalah juru bicara orang tua mereka, yang diutus untuk melakukan tugas Individu dan keluarga. Siswa harus tetap menjadi bagian komunitas, bersimpati dengan semua masalah sosial, dan menjadi bagian yang efektif untuk menyelesaikannya. Oleh karena itu, diperlukan peran kritis dan kepedulian mahasiswa dalam mengungkapkan kebutuhan masyarakat, serta mahasiswa yang Kreatif dan inovatif dalam menghadapi tantangan dan permasalahan yang dihadapi masyarakat. Ngomong-ngomong, orang tua mereka mengirim mereka sebagai duta.

(4) Mahasiswa adalah bagian dari komunitas dunia dengan ras dan etnis. Pengakuan terhadap keberagaman ini merupakan ciri dasar sikap toleran, saling menguntungkan dan humanistik untuk bekerjasama dalam mewujudkan tatanan masyarakat dunia yang adil dan makmur.

(5) Murid adalah manusia, mereka tidak dapat melampaui keberadaan takdirnya sebagai ciptaan Tuhan.Mereka menjalankan misi nabi untuk menjadi khalifah di bumi, bertanggung jawab atas kelangsungan hidup dan kesejahteraan semua makhluk di bumi. 
karena itu, siswa harus taat secara individu dalam melaksanakan ibadah formal dan menyadari Hakikat ibadah dalam kehidupan sehari-hari. Lima kesadaran tersebut hendaknya menjadi dasar bagi pengembangan pola dan teknik dalam mengasuh karakter peserta didik, sehingga ukuran internal Dimensi nilai dan keberadaannya dapat terjadi secara alamiah dan manusiawi. Tentunya ini bukan proses yang mudah, apalagi dalam organisasi universitas yang kompleks, dan seringkali terkendala oleh budaya birokrasi yang lamban, tidak efisien, dan formalistik.

Menurut teori klasik Aristoteles, politik adalah upaya warga negara untuk mewujudkan kepentingan bersama. Misalnya saja, masalah pemilihan rektor banyak mahasiswa yang meolak kebijakan tentang pemilihan rektor. Hal tersebut dikarenakan banyaknya prosentase suara yang dimiliki oleh mentri dfalam menentukan siapa yang akan menjadi rektor. Hal seperti itu seharusnya disikapai secara dewasa, dan tentunya disertai dengan pikiran yang positif. Karena tidak semua orang melakukan hal yang salah.

Orang yang berpandangan positif maka akan berfikir bahwa perguruan tinggi itu milik pemerintah, sehingga yang paling berhak menentukan siapa yang akan mengelola perguruan tinggi tersebut tentunya juga di tentukan oleh pemerintah. Orang yang duduk di pemerintah adalah orang yang sudah lebih berpengalaman dari kita selaku mahasiswa, dan mengetahui kualifikasi secara pasti mengenai orang yang akan dipilih. Sementara mahasiswa didibaratkan pasien dalam rumah sakit. Mahasiswa adalah pihak yang di proses,pihak yang nantinya akan dijadikan produk yang berkualitas, maslaah yang mengelola siapa yang penting hasilnya nanti akan menjadi baik.

Juga pasien di rumah sakit. Dia datang ke rumah sakit untuk memperbaiki kesehatannya. Dari siapapun yang sakit sampai yang ingin disembuhkan. Namun pada saat mereka di rawat di rumah sakit,lalu ada pergantian direktur rumah salkit, apakah mereka juga memiliki hak suara untuk memilih direktur rumah sakit? Tentu saja tidak. Alangkah dan baiknya jika sebagai mahasiswa seharusnya kita harus bersikap positif thingking terhadap pengelola kita, dan yakinlah siapapun pengelola kita akan memberikan yang terbaik bagi kita.

Pandangan lain adalah bahwa politik adalah sesuatu yang berkaitan dengan pemerintah dan negara, atau sesuatu yang bertujuan untuk mewujudkan dan memelihara kekuatan sosial. Pertanyaannya, apakah mahasiswa diperbolehkan mengikuti kegiatan politik? Politik dan mahasiswa tidak dapat dipisahkan, karena pada dasarnya manusia adalah tokoh politik atau politisi dengan segala binatang. Mahasiswa di kampus sebenarnya sudah dipolitisasi, terlihat misalnya ketika ketua senat mahasiswa dipilih, ketua badan eksekutif mahasiswa adalah ketua unit kegiatan mahasiswa dan lain-lain. Di luar kampus, mahasiswa yang memenuhi persyaratan usia dapat menjadi anggota partai politik. Namun, hanya sedikit mahasiswa yang tidak peduli dengan politik dan acuh tak acuh terhadap masalah politik, bahkan ada yang mengatakan bahwa politik itu licik dan kotor, Siswa harus memainkan peran yang sangat penting dalam negara dan kemajuannya. Mahasiswa sebagai agen perubahan adalah "agen perubahan. Hampir semua perubahan politik di negeri ini dilakukan oleh mahasiswa." Perubahan yang sedang terjadi di negeri ini sangat membutuhkan kepemimpinan dari para mahasiswa, mereka juga bisa disebut atau bisa disebut oleh mahasiswa sebagai pemrakarsa perubahan.

Tapi ada Gerakan politik mahasiswa saat ini sering ditampilkan dalam demonstrasi dan diakhiri dengan tindakan anarkis, seperti merusak infrastruktur yang ada, membakar ban di tengah jalan, dan menghalangi pengguna jalan lainnya. Yang lain percaya bahwa gerakan mahasiswa itu aktif dan hanya untuk kepentingan kelompok atau kelompok.

Berkaitan dengan hal tersebut, maka sangat penting bagi mahasiswa untuk melaksanakan pendidikan politik sebelum melaksanakan hak politiknya agar tahapan kedewasaan politiknya semakin matang, sehingga tidak menjadi anarkis dalam menyampaikan keinginannya tersebut. Pendidikan kewarganegaraan dapat digunakan 
untuk membangun kematangan politik peserta didik sebagai kelompok akademis, dan pendidikan kewarganegaraan merupakan salah satu mata kuliah wajib dalam pendidikan tinggi.

Pada tahun 2012 UU Pendidikan Tinggi No. 12, mata kuliah pendidikan kewarganegaraan merupakan matakuliah wajib, artinya setiap matakuliah universitas pasti ada matakuliahnya. Pendidikan kewarganegaraan hanyalah tentang belajar menjadi orang Indonesia, belajar menjadi pribadi Orang yang berkepribadian di Indonesia, memiliki kebangsaan dan cinta tanah air. Oleh karena itu, calon sarjana atau profesional adalah bagian dari masyarakat Orang Indonesia yang terpelajar perlu memahami Indonesia, berkepribadian Indonesia, memiliki rasa kebangsaan Indonesia, dan mencintai tanah air Indonesia. Oleh karena itu, ia menjadi warga negara yang terpelajar (warga negara yang cerdas dan baik) dalam kehidupan masyarakat, negara dan negara yang demokratis.

Seperti yang tertuang dalam UU No.1. Informasi tentang sistem pendidikan nasional 20-20 tahun 2003 juga menunjukkan bahwa peran pendidikan nasional adalah mengembangkan keterampilan untuk membentuk karakter dan peradaban bangsa, serta mencerdaskan kehidupan bangsa guna mengembangkan potensi peserta didik dan menjadikan peserta didik percaya dan berperilaku. Kemampuan, gaya luhur, sehat, berpengetahuan luas dan mampu. Warga negara yang tangguh, kreatif, mandiri, dan demokratis. Pendidikan yang menjadikan masyarakat demokratis dan bertanggung jawab adalah pendidikan yang demokratis.

Pendidikan demokrasi yang merupakan salah satu materi dalam pendidikan kewarganegaraan di negara yang menganut sistem demokrasi merupakan sesuatu yang penting untuk dilaksanakan dari sejak awal secara terencana, terstruktur, dan berkelanjutan. Hal ini jangan sampai ada penyalahgunaan demokrasi yang dapat berujung pada perilaku anarkhi.

Jika demokrasi tidak dibarengi dengan hukum dan politik hukum dan tatanan politik yang jelas, ada beberapa situasi yang akan berubah menjadi anarkisme, kemudian mengarah pada rezim, yaitu penindasan pemerintah dan pelanggaran prinsip demokrasi.

Pendidikan demokrasi yang dibutuhkan untuk membentuk masyarakat sipil Indonesia mengandung banyak unsur.

a) Manusia membutuhkan kebebasan politik, yang berarti mereka membutuhkan aturannya sendiri;

b) Kebebasan pengetahuan;

c) Kesempatan untuk berpartisipasi dalam realisasi diri;

d) Pendidikan yang membangun ikatan moral dengan kepentingan bersama daripada kepentingan pribadi atau kepentingan kelompok;

e) Pendidikan yang mengakui perbedaan hak (different rights) percaya pada kemampuan masyarakat untuk membangun masyarakat di masa depan.

Dari sekolah dasar hingga pendidikan tinggi, disiplin dengan visi dan misi yang jelas untuk pendidikan demokrasi adalah pendidikan kewarganegaraan.

Pendidikan Kewarganegaraan Bisa dikatakan pendidikan politik, pendidikan moral dan nilai, pendidikan nasional, pendidikan sosial, pendidikan hukum, dan pendidikan hak asasi manusia dan demokrasi.Mereka meyakini bahwa: secara umum warga negara mempunyai fungsi strategis untuk mencapai hakikat tujuan pendidikan nasional dan membentuk demokrasi dan negatif. Warga negara yang bertanggung jawab. Jawaban: Menurut Lemhanas, dalam penyelenggaraan pendidikan kewarganegaraan juga melaksanakan tugas-tugas lain, yaitu:

(1) Pendidikan kewarganegaraan dalam arti yang sebenarnya adalah pendidikan kewarganegaraan yang membantu mengembangkan dan

mengembangkan pengetahuan dan keterampilan Mengenai peran, tanggung jawab, hak dan kewajiban serta tanggung jawab warga negara;

(2) Pendidikan dan budi pekerti, sebagai proses dan untuk pengembangan apapun yang dianggap sebagai kebaikan nasional, 
Membentuk warga negara yang bermoral baik;

(3) Peran pendidikan keamanan nasional adalah agar peserta didik memiliki pemahaman tentang keamanan nasional sehingga dapat diandalkan dan diuntungkan darinya, guna menjaga agar negara tetap bertahan dalam menghadapi berbagai ancaman.

Pendidikan kewarganegaraan telah menjadi Suatu bentuk pendidikan bagi generasi penerus yang bertujuan agar mereka menjadi warga negara yang tajam dan sadar akan hak dan kewajibannya dalam masyarakat dan negara, serta agar semua warga negara menjadi warga global yang cerdas. siap-siap. Pendidikan kewarganegaraan sangat penting agar peserta didik menjadi orang yang memahami hak dan kewajiban warga negara Indonesia, berfikir serius, bertoleransi, dan cinta damai, serta menjadi orang yang memahami dan berpartisipasi dalam kehidupan politik lokal, nasional dan internasional. Metode pembelajaran semacam ini merupakan metode pembelajaran yang berpusat pada siswa, yang memberikan siswa lebih banyak kesempatan untuk berdialog atau berdiskusi dan membuat mereka lebih aktif di dalam kelas. karena itu, siswa akan lebih memahami peran penting yang mereka mainkan dalam kehidupan berbangsa dan bernegara.

Dari pendidikan dasar hingga Pendidikan tinggi disiplin ilmu dengan visi dan misi yang jelas adalah pendidikan yang demokratis. Pembentukan kewarganegaraan melibatkan banyak faktor, antara lain:

Satu jenis. Hubungan antara pengetahuan kognitif dan pengetahuan perseptual atau hubungan antara agama dan sains.

b. Sasaran budaya dan pendidikan nasional Indonesia.

c. Disiplin pendidikan, terutama psikologi pendidikan.

d. Disiplin ilmu sosial, khususnya kewarganegaraan. e. Terutama Pancasila, Undang-Undang Dasar Negara Republik Indonesia Tahun 1945, serta peraturan perundang-undangan nasional dan sejarah perjuangan bangsa.

\section{f. Aktivitas dasar manusia.}

g. Pengertian pendidikan ilmu sosial. Ketujuh elemen ini akan mempengaruhi perkembangan warga.

Karena perkembangan pendidikan kewarganegaraan akan mempengaruhi pemahaman warga, inilah salah satu tujuan pendidikan penelitian sosial.

Pendidikan kewarganegaraan yang mengajarkan tidak hanya warga negara bagaimana tunduk dan tunduk kepada negara tetapi juga mengajarkan bagaimana warga negara harus toleran dan mandiri. Pendidikan ini memungkinkan semua generasi penerus memiliki pengetahuan, pengembangan keterampilan, serta pengembangan karakter. Membina hubungan dengan lingkungan yang lebih luas merupakan bagian dari pendidikan nasional.

Meskipun mungkin untuk mempelajari perkembangan ini tanpa berpartisipasi dalam pendidikan kewarganegaraan, yang terbaik adalah menggunakan pendidikan ini untuk pengembangan diri yang luas. Keterampilan sipil yang lebih tinggi untuk sementara akan membuat kita kehilangan minat pada kemuliaan. Selain itu, kami tidak rentan terhadap pengaruh budaya non-Indonesia, dan kami menghormati semua budaya dan nilai yang berlaku di negara kami. Jika kita tidak belajar, tentu kita tidak bisa mendapatkan sikap ini.

Oleh karena itu, manfaat pendidikan kewarganegaraan menjadi sangat penting, sehingga kedepannya harus ada perubahan yang mendasar pada konsep, petunjuk, materi, metode, dan penilaian pembelajaran. Tujuannya untuk membangun kesadaran siswa tentang hak dan kewajiban warga negara serta dapat menggunakannya secara demokratis dan berpendidikan tinggi. Keyakinan masyarakat Indonesia bahwa nilainilai yang baik juga telah berubah. Hal ini pula yang membuat para siswa seolah-olah 
telah kehilangan nilai luhur negeri ini. Perubahan nilai tersebut dapat terjadi karena dua faktor yaitu faktor internal dan faktor eksternal. Faktor eksternal adalah pengaruh globalisasi yang masuk ke negara kita. Sedangkan faktor internal merupakan faktor yang berasal dari Indonesia sendiri. Contoh faktor eksternal adalah globalisasi. Globalisasi digerakkan oleh liberalisme yang mendorong lahirnya sistem kapitalis di bidang ekonomi dan kebebasan politik dan demokrasi.

Munculnya sistem baru seperti ini dapat mengubah tatanan dunia regional lama menjadi tatanan global baru. Nilai-nilai baru dan masukan sistem dari luar akan mengarah pada lompatan atau pergeseran dalam sistem nilai. Ada pertanyaan tentang menerima nilainilai baru ini atau mempertahankan nilai-nilai dasar yang dianut oleh negara kita. Sedangkan contoh faktor internal adalah yang berasal dari negara Indonesia sendiri. Hal ini mungkin terjadi karena kurangnya pengetahuan warga tentang Pancasila. Pancasila dianggap sebagai alat legitimasi orde baru dan tidak dapat menyelesaikan krisis yang dihadapi negara saat ini. Pemikiran seperti ini membuat semakin banyak orang merasa lebih ringan dan ringan terhadap Pancasila, dan karenanya menjadi jijik dengan Pancasila.

Kesalah pahaman Dengan cara ini masyarakat telah kehilangan sumber daya dan sumber daya untuk mengarahkan dirinya pada nilainilai sikap anti pancasila tersebut. Hal tersebut dapat menimbulkan masalah baru dalam masyarakat yaitu merosotnya sikap terhadap nasionalisme.

Pendidikan dan pembelajaran Pancasila dan kewarganegaraan mengarah pada pelembagaan keutamaan kewarganegaraan untuk mewujudkan kehidupan berbangsa dan bernegara yang harmonis, yang dicapai melalui pengembangan pengetahuan kewarganegaraan,

kewarganegaraan, dan karakter kewarganegaraan, seperti terlihat pada gambar di bawah ini. Berdasarkan uraian di atas, nilai-nilai seperti berikut ini dapat dilihat pada diri siswa: terwujudnya nilai-nilai Pancasila dalam kehidupan bermasyarakat, berbangsa dan bernegara; pengamalan Undang-Undang Dasar Negara Republik Indonesia Tahun 1945 dalam Pembukaan Undang-Undang Dasar 1945 dalam kehidupan berbangsa dan bernegara. Nilainilai; Mengamalkan nilai-nilai yang terkandung dalam Undang-Undang Dasar Negara Republik Indonesia Tahun 1945 dalam segala aspek ideologi, politik, ekonomi, sosial budaya, pertahanan dan keamanan nasional, serta kehidupan hukum; mengamalkan sikap toleransi antarumat beragama dan kepercayaan di dalam kehidupan. bermasyarakat,berbangsa,dan bernegara;

Pendidikan kewarganegaraan pada dasarnya merupakan salah satu bentuk pendidikan untuk generasi penerus. Tujuannya adalah untuk memungkinkan mereka menjadi warga negara yang berpikiran tajam dan sadar akan hak dan kewajiban mereka dalam kehidupan bermasyarakat dan bernegara, serta memungkinkan semua warga negara menjadi warga global. Siap. pintar. Dalam pendidikan kewarganegaraan ini siswa diingatkan kembali bahwa bangsa Indonesia dibangun di atas keragaman suku, budaya dan agama. Saling menghormati dan saling menghormati. Ajarkan warga negara bagaimana tidak hanya mematuhi dan mematuhi negara, tetapi juga mengajarkan warga bagaimana menjadi toleran dan mandiri. Pendidikan tersebut memungkinkan setiap generasi memiliki pengetahuan, pengembangan keterampilan, dan pengembangan publik. Pengembangan komunikasi dengan lingkungan yang lebih luas juga termasuk dalam pendidikan kewarganegaraan.

Meski perkembangan ini bisa dipelajari tanpa menempuh Pendidikan Kewarganegaraan, alangkah baiknya jika pendidikan ini digunakan untuk pengembangan diri secara maksimal. Rasa kewarganegaraan yang tinggi akan mudah dipengaruhi oleh nafsu sukses sementara. Selain itu, tidak akan mudah terpengaruh secara langsung oleh budaya yang bukan berasal dari Indonesia dan juga menghormati semua budaya dan nilai yang ada di Indonesia. Memiliki sikap ini, tentunya tidak mungkin dilakukan tanpa belajar. Mengingat manfaat Pendidikan 
Kewarganegaraan yang sangat penting, terutama dalam proses membangun kematangan politik di lingkungan sivitas akademika, ke depan kualitas pembelajaran Pendidikan Kewarganegaraan harus ditingkatkan. Kompetensi yang diharapkan setelah mahasiswa mengikuti mata pelajaran Pendidikan Kewarganegaraan ini antara lain agar mahasiswa mampu menjadi warga negara yang memiliki pandangan dan komitmen terhadap nilai-nilai demokrasi dan HAM, Sehingga siswa dapat berpartisipasi dalam upaya cerdas dan damai mencegah dan menghentikan berbagai tindak kekerasan, sehingga siswa dapat menambah kekhawatirannya dan berpartisipasi dalam upaya penyelesaian konflik di masyarakat yang ada Berdasarkan nilai moral, agama dan universal, sehingga siswa dapat berpikir kritis dantujuan dari permasalahan kebangsaan, hak asasi manusia dan demokrasi, agar mahasiswa dapat berkontribusi dan mencari solusi atas berbagai isu kebijakan publik, sehingga mahasiswa dapat mendefinisikan nilai-nilai intinya secara hati-hati (beradab).

\section{KESIMPULAN}

Sikap dan perilaku siswa dalam pelaksanaan hak politik yang terkadang mengarah pada perilaku yang tidak tepat menunjukkan sikap belum dewasa. Namun, kematangan politik tidak bergantung pada usia seseorang. Orang tua masih eksis dan sikap serta perilaku mereka masih belum berkembang sepenuhnya. Mahasiswa, sebagai warga sivitas akademika, yang mungkin merupakan pemimpin bangsa, harus memiliki karakter dan perilaku yang matang. Pendidikan sipil perguruan tinggi memuat materi pendidikan yang berkaitan erat dengan pembinaan sikap dan perilaku mahasiswa dengan budi pekerti, budi pekerti, etika dan perilaku, serta prilaku bikinan sendiri.

Pendidikan Kewarganegaraan ini dapat menjadi sarana pembentukan Berkarakter menjadikan santri warga negara yang baik, cerdas dan dewasa dalam berpolitik, sehingga Pendidikan Kewarganegaraan dapat dikatakan mendukung kematangan politik di lingkungan sivitas akademika. Berdasarkan kesimpulan Sehubungan dengan itu, disarankan agar pemerintah terus menjadikan mata kuliah PKn sebagai mata pelajaran wajib di semua jenjang pendidikan, dan terus mengawasi proses pengajaran mata kuliah PKn di semua perguruan tinggi. Mahasiswa sebagai salah satu elemen terpenting dalam kehidupan demokrasi harus memberikan kontribusi yang nyata. Walaupun adanya pergeseran pergerakan mahasiswa antar rezim, hal itu tidak memudarkan peran mahasiswa sebagai pengawal dan pengawas setia kegiatan pemerintahan.

Kedudukan mahasiswa dalam sistem politik pun memiliki posisi penting, mahasiswa dianggap sebagai kaum elit yang sadar akan perannya dalam kehidupan politik. Tidak heran bahwa kegiatan-kegiatan mahasiswa banyak yang bersifat kritis dan menekan. Terkadang idealisme yang dimiliki mahasiswa harus diekspresikan, walaupun caranya bersebrangan dengan keinginan pemerintah.

Status quo saat ini mahasiswa seperti kehilangan orientasi dalam kehidupan demokrasi dan politik. Hal tersebut akan menimbulkan sifat-sifat yang buruk terhadap kehidupan demokrasi, seperti apatisme, hedonisme, dan sebagainya. Patut di apresiasi terhadap mahasiswa yang pada saat ini masih memiliki orientasi yang jelas dalam kehidupan demokrasi dan melakukan pergerakan nyata untuk mengekspresikannya.

Satu hal terpenting yang jarang disadari oleh mahasiswa adalah perannya sebagai jembatan penghubung antara kelas bawah (under class) kepada kelas atas (upper class). Kelas bawah dapat diartikan sebagai masyarakat yang tidak memiliki kemampuan untuk mempengaruhi kebijakan pemerintah, sedangkan kelas atas dapat diartikan sebagai sekelompok orang yang memiliki kemampuan untuk membuat kebijakan.

$\begin{array}{lcr}\text { Dalam } & \text { konteks ini pengertian } \\ \text { pendidikan } & \text { kewarganegaraan } & \text { dapat } \\ \text { dirumuskan } & \text { sebagai } & \text { berikut: }\end{array}$

Kewarganegaraan sebagai salah satu tujuan pendidikan ilmu sosial yang menekankan pada nilai-nilai pembinaan warga negara yang baik dan patriotik. Pendidikan Kewarganegaraan adalah seleksi dan adaptasi ilmu-ilmu sosial, kewarganegaraan, dan 
aktivitas dasar manusia yang disusun dan disajikan secara psikologis dan ilmiah untuk mencapai salah satu tujuan pendidikan ilmu sosial. Beberapa faktor yang menjelaskan lebih lanjut pendidikan kewarganegaraan termasuk;

Sebuah. PKN merupakan bagian atau tujuan dari tujuan pendidikan penelitian kemasyarakatan, yaitu pendidikan yang terintegrasi secara integral dengan berbagai disiplin ilmu sosial, dokumen kenegaraan khususnya Pancasila, dan hukum negara yang menitikberatkan pada materi pendidikan tentang kewarganegaraan dan hubungan dengan negara. Materi pendidikan terkait pertahanan negara.

b. PKn dipilih dari berbagai ilmu sosial, humaniora, Pancasila, UUD NRI 1945 dan dokumen nasional lainnya, yang disusun secara ilmiah dan ilmiah untuk kepentingan pendidikan.

c. PKN dikembangkan untuk tingkat jurusan PMPKN FPIPS dan untuk pendidikan dasar dan menengah serta perguruan tinggi. Itu telah dibuat secara ilmiah dan psikologis.

d. Dalam proses pembinaan dan pelaksanaan kewarganegaraan, kita harus membedakan secara komprehensif antara ilmu internal (agama, nilai) dan ilmu eksternal (ilmu pengetahuan), kebudayaan Indonesia, tujuan pendidikan nasional, Pancasila, UUD1945, GBHN, dan filsafat. Hubungan antara pengembangan kurikulum pendidikan yang komprehensif dan terintegrasi, psikologi, dan disiplin ilmu sosial, kemudian merumuskan rencana pendidikan yang meliputi: (i) sasaran pendidikan, (ii) materi pendidikan (iii) metode pendidikan, (iv) evaluasi.

e. Warganegara menekankan pada kemampuan berpikir positif warga negara, khususnya generasi muda, dan menginternalisasi nilai-nilai warga negara sekaligus menyelesaikan berbagai masalah sosial (urusan sipil) dalam suasana demokrasi. f. Di perpustakaan luar negeri, kewarganegaraan biasanya disebut sebagai pendidikan sipil, Salah satu keterbatasannya adalah "semua kegiatan sekolah, keluarga dan masyarakat yang dapat mendorong demokrasi.

Kewarganegaraan sebagai pendidikan nilai dapat membantu siswa memilih sistem nilai yang dipilihnya dan mengembangkan aspek emosional yang akan diwujudkan dalam perilaku mereka. Seperti yang diungkapkan dalam proses belajar mengajar, beberapa orang percaya bahwa pendidikan nilai bertujuan untuk membantu siswa mengembangkan perilaku mereka dan memperkuat sistem nilai yang mereka pilih sebagai dasar perilaku mereka. Pengembangan nilai didasarkan pada sikap yang berkembang, sehingga berbeda dengan pembelajaran melalui pendidikan kognitif atau psikomotorik.

Di Indonesia kreasi nilai formal diberi tema PPKn yaitu pembentukan nilai-nilai Pancasila, agar mereka bisa menjadi pelaku. Pendidikan kewarganegaraan dapat dianggap sebagai pendidikan politik, pendidikan moral dan etika, pendidikan nasional, pendidikan sosial, pendidikan hukum dan hak asasi manusia, dan pendidikan demokrasi. Balas "Menurut pelatihan pendidikan kewarganegaraan, ia juga menjalankan misi lain sebagai:

(1) Pendidikan sipil dalam arti yang sebenarnya, yaitu pendidikan nasional membantu menumbuhkan dan mengembangkan pengetahuan dan keterampilan melalui tanggung jawab, tugas, hak, kewajiban, dan tanggung jawab warga negara;

(2) Pendidikan nilai dan karakter yang bertugas memajukan dan mengembangkan nilai-nilai kebangsaan yang dipandang baik guna mewujudkan warga negara yang bermutu;

(3) Pendidikan Keamanan Nasional, yang berperan mengoordinasikan peserta didik untuk memberikan pencerahan terhadap 
keamanan nasional agar dapat diandalkan dan diuntungkan oleh kelangsungan bangsa dari berbagai ancaman. Pendidikan kewarganegaraan merupakan salah satu bentuk pendidikan bagi generasi penerus. Tujuan mereka adalah untuk membuat mereka beradab, untuk lebih memahami hak dan tanggung jawab mereka dalam kehidupan publik dan nasional dan untuk membuat semua warga negara menjadi dunia yang bijaksana. Warga sudah siap. Pendidikan kewarganegaraan sangat penting bagi peserta didik untuk menjadi orang yang memahami hak dan kewajiban warga negara Indonesia, berpikir keras, memiliki toleransi yang tinggi, cinta damai, dan menjadi orang yang memahami dan berpartisipasi dalam kehidupan politik. lokal, nasional dan internasional.

Prinsip pembelajaran tersebut adalah prinsip belajar aktif siswa (pembelajaran aktif bagi siswa), pembelajaran kelompok (pembelajaran kolaboratif), pembelajaran partisipatif, dan pembelajaran pasif (pembelajaran pasif). Adapun penjelasan dari keempat prinsip tersebut adalah sebagai berikut .

1. Prinsip Pembelajaran Aktif untuk Siswa Model ini memuat aturan-aturan belajar aktif siswa. Mulai dari perencanaan kurikulum, kegiatan dan pelaporan, siswa menyelesaikan hampir setiap proses pembelajaran. Dalam bidang koordinasi, hasil karya siswa akan teridentifikasi saat masalah diidentifikasi melalui teknik otak. Selain soal-soal yang berkaitan dengan topik, setiap siswa dapat mengajukan pertanyaan yang menarik. Setelah mengumpulkan pertanyaan, siswa memilih satu pertanyaan untuk pembelajaran kelas.

Pada fase aksi lokal, pergerakan mahasiswa lebih terasa. Mereka menggunakan berbagai teknik (seperti wawancara, observasi, mengajukan pertanyaan, dll. ) Untuk mengumpulkan data dan informasi yang diperlukan untuk menjawab pertanyaan di kelas. Untuk mengisi data dan informasi, mereka akan mengambil gambar, membuat gambar, mengalahkan koran, dan terkadang bahkan menangkap elemen penting dari video tersebut.

2. Proses pembelajaran PKn dalam kelompok belajar kolaboratif juga mengadopsi prinsip belajar kolaboratif, yaitu proses pembelajaran kolaboratif. Kolaborasi yang dimaksud adalah kolaborasi antara siswa dengan jurusan lain di sekolah, termasuk kolaborasi sekolah dengan orang tua siswa dan lembaga. negara bagian terkait. Ketika siswa memilih masalah dengan materi pembelajaran yang familiar, kolaborasi siswa akan terlihat.

Kolaborasi dengan departemen lain di sekolah seringkali diperlukan. Misalnya, ketika siswa ingin mengumpulkan data dan informasi lapangan setelah lulus, mereka juga dapat menunda waktu melalui olahraga atau karyawisata. Meski kasus seperti itu kecil dan luas, mereka juga membutuhkan kerja sama. Hal serupa sering terjadi dalam keluarga. Saat anak pulang sekolah, orang tua perlu diberi tahu karena harus melakukan karyawisata terlebih dahulu. Sekali lagi, kasus ini juga menunjukkan bahwa sekolah dan orang tua perlu bekerja sama untuk membangun pemahaman.

Ketika siswa berencana untuk mengunjungi institusi tertentu atau mengunjungi area yang bertanggung jawab untuk institusi tertentu, mereka perlu bekerja sama dengan institusi terkait. Misalnya, kunjungi layanan parkir. Kunjungi kantor walikota atau walikota untuk mengetahui kebijakan yang mengatur pedagang kaki lima. Lihat dampak daur ulang sampah di suatu area, dll. Tentunya perlu adanya surat pengantar dari kepala sekolah untuk bertanggung jawab atas kegiatan pergerakan siswa di sekolah.

3. Partisipasi belajar Selain prinsip-prinsip yang dipelajari di atas, warga juga mengikuti prinsip-prinsip dasar mengikuti pembelajaran, karena dengan cara ini mereka dapat belajar sambil melakukan (learning by membuat) siswa. Salah satu bentuknya adalah siswa belajar dan hidup di negara demokrasi. Karena pada setiap tahapan pemaknaan model berkaitan dengan penerapan kehidupan demokrasi.

Misalnya, ketika memilih pertanyaan untuk pembelajaran di kelas, pilihlah arti dari perspektif yang paling dihargai dan diterima 
siswa. Dalam suatu diskusi, siswa belajar mengekspresikan diri, mendengarkan pendapat orang lain, menyampaikan kritik atau menerima kritik ketika kepala mereka bersih.

Salah satu cara untuk menciptakan konsolidasi demokrasi atau kedewasaan demokrasi adalah membangun kesamaan pemahaman mahasiswa untuk berperan aktif dalam kehidupan demokrasi dan politik. Serta membangun bersama budaya politik yang sehat bagi kehidupan demokrasi kita, sehingga pada akhirnya disorientasi mahasiswa tidak akan terjadi.

Tidak bisa dipungkiri bahwa mahasiswa memiliki peran penting dalam kehidupan demokrasi. Akan tetapi di era digital dan modernisasi ini kualitas peran mahasiswa menyurut. Kehidupan yang serba praktis membuat pola pikir mahasiswa pun praktis. Ketika dihadapkan masalah atau isu-isu yang berhubungan dengan politik atau demokrasi, banyak mahasiswa yang enggan memperjuangkan atau membuat suatu pergerakan yang nyata untuk memecahkan masalah tersebut.

Keengganan mahasiswa tersebut bukanlah tanpa sebab. Tumpulnya pergerakan mahasiswa berkaitan erat dengan eksistensi diri, mereka menganggap bahwa ketika terlibat dalam kehidupan poitik atau demokrasi eksistensi diri tidak akan didapatkan. Hal tersebut merupakan efek laten dari berkembangnya teknologi terhadap peran mahasiswa.

Demokrasi memberikan nafas baru untuk kita agar memiliki kehidupan yang baik serta berupaya untuk mensejahterakan rakyat. Transisi demokrasi seakan tersendat dengan permasalahan-permasalahan yang menyulut identitas masyarakat itu sendiri, seperti etnisitas, agama, suku, budaya, dan sebagainya. Dimas Okky Nugroho (Staff Khusus Kepresidenan) mengatakan bahwa demokrasi akan hancur bukan karena permasalahan perbedaan identitas, akan tetapi negara akan hancur karena ketidak adilan itu sendiri.

Maka dari itu, pesan terpenting demokrasi dalam Kehidupan berbangsa dan bernegara merupakan upaya menegakkan keadilan yang seadil-adilnya. Baik itu keadilan dalam hukum, keadilan dalam politik, keadilan dalam kehidupan sosial, dan sebagainya. Hal tersebut merupakan tugas bersama terkhusus bagi pemerintah dan mahasiswa sebagai agent of change.

Berbagai macam cara mahasiswa atau masyarakat secara umum dalam memberikan pengaruhnya di kehidupan politik, baik itu cara formal maupun cara yang bersifat informal. Demokrasi memberikan ruang yang luas bagi masyarakat untuk berpendapat dan mengkritik kebijakan pemerintah. Akan tetapi, salah satu patologi dalam demokrasi akan muncul ketika pemerintah menciptakan ruang yang sempit bagi warga negara untuk menjalankan haknya, terutama hak untuk berpendapat.

Salah satu jalan yang sampai saat ini tetap eksis adalah melalui demonstrasi. Demonstrasi terjadi bukan tanpa sebab, tahapan-tahapan yang panjang dan matang membuat keyakinan masyarakat untuk melakukan demonstrasi. Sebagai jalan terakhir, demonstrasi diharapkan dapat menekan dan dapat mempengaruhi Itu tidak dianggap sebagai kebijakan pemerintah yang dekat dengan rakyat. Kita semua menyadari bahwa melalui demonstrasi kebijakan itu tidak akan berubah, karena kewenangan tetap berada ditangan pemerintah. Akan tetapi, demonstrasi hanya dapat menekan pemerintah agar kebijakan tersebut dapat berubah. Demonstrasi merupakan jalan terakhir dalam perjuangan demokrasi, demonstrasi akan mendapatkan citra yang buruk ketika pelaksanaannya chaos dan pemerintah tidak memberikan ruang bagi para demonstran.

Inilah demokrasi, sistem yang begitu bising tetapi memberikan hak-hak yang luas kepada manusia. Kemampuan pemerintah dalam mengelola demokrasi diuji ketika isu-isu demokrasi muncul kepermukaan. Pendewasaan demokrasi akan terus berjalan seiring dengan kesadaran warga negara khususnya mahasiswa untuk melindungi hakhak orang lain dan memberikan kontribusi nyata dalam proses konsolidasi demokrasi. 


\section{DAFTAR PUSTAKA}

Ahadi, Muhammad. Peran pendidikan kewarganegaraan dalam mempromosikan pola pikir bernegara. Seminar Nasional Sekolah Tinggi Ilmu Sosial Tahunan Universitas Medan Medan. Azyumardi Azra. 2003 Demokrasi, hak asasi manusia, masyarakat sipil. Prenada Media, Jakarta. Budimansyah, D. (2012). Dimensi praktik pendidikan karakter. Bandung Via Aksala Press. Budimansyah, D, Suryadi, K. (2008). Semua kelompok etnis dan komunitas. Kogan, Laboratorium Pendidikan Nasional Bandung, John J. dan Ray Derrickt. (1998). "Kewarganegaraan di Abad 21: Perspektif Internasional tentang Pendidikan." Untuk London Cogan. Lemhanas, pendidikan kewarganegaraan. Miriam Budiardjo. Pada tahun 2005. Yayasan IImu Politik, Gramedia Pustaka Utama, Jakarta, _ 2008. Yayasan Ilmu Politik (Edisi Revisi), Jakarta Gramedia Nasution, S. Metodologi Penelitian Kualitatif Alam, Bandung Tassito. Ubaeidilah dan Abdul Rozak, Pendidikan Nasional di Jakarta, ICCE UIN Syarif Hidayatullah. Winarno, 2007. Paradigma baru pendidikan nasional dalam "Penelitian Sastra Jakarta".Amerika Serikat, Winataputra (2012). Pendidikan kewarganegaraan mendidik kehidupan negara dari perspektif pendidikan. Wandya Aksara Press Winataputra, Uddin S dan D. Budimansyah. (2012). Pendidikan Kewarganegaraan Internasional (Latar Belakang, Teori dan Profil Studi. Bandung Vidia Aksala Press. UndangUndang Nomor 20 Tahun 2003 tentang Sistem Pendidikan Nasional Undang-Undang Republik Indonesia Nomor 12 Tahun 2012, tentang Pendidikan Tinggi.

http://dodisupandiblog.blogspot.com/ https://www.educenter.id/pendidikankarakter-pada-usia-dini/ http://kelompok2abb.blogspot.com/ 